\title{
Variabilitas dan Heritabilitas Karakter Penting beberapa Genotip Padi Sawahpada Cekaman Salinitas Tinggi
}

\author{
Variability and Heritability Some Field Rice Genotype Important Characters \\ on High Salinity Pressure
}

\author{
Roni Assafaat Hadi, Raden Budiasih \\ Program Studi Agroteknologi, Fakultas Pertanian, Universitas Winaya Mukti \\ roni.assafaat.hadi@gmail.com \\ Program Studi Agroteknologi, Fakultas Pertanian, Universitas Winaya Mukti \\ budiasihenty@gmail.com
}

\begin{abstract}
The objective of the research was to know the variability and heritability some field rice genotype important characters on high salinity pressure. The research was carried on Laboratory and Screen House of Balai Pengawasan dan Sertifikasi Benih Tanaman Pangan dan Hortikultura, Bandung with the altitude is $600 \mathrm{~m}$ above sea level. The time of the research was started on October 2011 until February 2012. The research used experimental methods and Randomized Block Design with 16 field rice genotype and replicated 2 times. The main observation variables are plant height, weight of dry shoot, weight of dry root, relativity of shoot and root, age of flowering, age of harvest, number of tassel per plant, number of rice per plant, percentage of empty rice per plant, weight of 1000 grain seeds per plant and result of unhulled rice per plant. The research and also showing different expected value heritability for important characters of field rice on high salinity pressure. High heritability value held by age of harvest 0,52; number of tassel per plant 0,95; number of rice per plant 0,978; percentage of empty rice 0,96 and weight of 1000 grain seeds 0,81 characters. For plant height 0,31 and age of flowering 0,42 characters including to middle heritability. While for low heritability value there are weight of dry shoot -0,028; weight of dry root $-0,082$; relativity of shoot and root $-0,25$ and result of unhulled rice per plant 0,11 characters.
\end{abstract}

\section{Keywords $\quad$ : Variability, Heritability, Field Rice Genotype and High Salinity} Pressure

\section{PENDAHULUAN}

Beras merupakan makanan pokok masyarakat di Indonesia. Kebutuhan akan beras bagi Indonesia dari tahun ke tahun akan semakin meningkat seiring dengan pertambahan jumlah penduduk. Dengan populasi sebesar 230 juta jiwa dan tingkat pertumbuhan penduduk sebesar $1,4 \%$ per tahun, pasokan beras pada saat ini telah mencapai tingkat terendah dalam kurun waktu 30 tahun terakhir yang disertai oleh kenaikan harga beras dalam 10 tahun terakhir (ACIAR-SADI, 2009). Hal tersebut diakibatkan luas lahan pertanian yang semakin hari semakin berkurang akibat alih fungsi lahan dan juga faktor lain seperti perubahan iklim global.
Curah hujan yang tidak menentu karena perubahan iklim mempengaruhi waktu tanam padi di sejumlah sentra padi mundur yang mengakibatkan waktu panen ikut mundur dan berujung pada naiknya harga beras di tengah masyarakat. Dampak dari perubahan iklim (climate exchange) adalah meningkatnya kejadian iklim ekstrim, berubahnya pola hujan, bergesernya awal musim, banjir, kekeringan dan naiknya permukaan air laut, yang mengakibatkan kondisi tanaman mengalami cekaman. Cekaman yang terjadi diantaranya adalah cekaman salinitas, dimana cekaman salinitas terjadi sebagai akibat deposit garam. Menurut Badan Penelitian dan Pengembangan Pertanian (2007), lahan salin yaitu lahan yang 
mendapat intrusi air laut sehingga mengandung garam dengan konsentrasi yang tinggi, terutama pada musim kemarau luasannya sekitar $2 \%$. Pada lahan-lahan pantai sering memunculkan tanah-tanah salin sebagai akumulasi garam akibat kekeringan pada musim kemarau (Sumarsono dkk., 2006).

Pengaruh utama salinitas adalah berkurangnya pertumbuhan daun yang langsung mengakibatkan berkurangnya fotosintesis tanaman. Salinitas mengurangi pertumbuhan dan hasil tanaman pertanian penting dan pada kondisi terburuk dapat menyebabkan terjadinya gagal panen. Pada kondisi salin, pertumbuhan dan perkembangan tanaman terhambat karena akumulasi berlebihan $\mathrm{Na}$ dan $\mathrm{Cl}$ dalam sitoplasma, menyebabkan perubahan metabolisme di dalam sel.

Lahan salin di Indonesia akan semakin meningkat mengingat Indonesia merupakan negara kepulauan yang mempunyai garis pantai yang panjang dengan daerah produksi padi di Indonesia berada di pinggir pantai seperti di pulau Jawa, Sulawesi dan yang lainnya. Disamping itu banyaknya bencana alam seperti gempa bumi yang mengakibatkan tsunami dan abrasi air laut juga memperluas lahan salin di Indonesia. Masalah salinitas telah menjadi masalah nasional yang harus ditangani, terutama sekali untuk mempertahankan atau meningkatkan produksi padi di Indonesia (Hasil Sembiring and Anischan Gani, 2005).

Penanaman padi pada lingkungan cekaman salinitas secara umum dikenal di masyarakat Indonesia dengan sebutan penanaman padi pasang surut, hal ini didasarkan pada pernyataan Widjaya - Adhi dkk. (1990), karena keragamannya yang besar lahan pasang surut diklasifikasikan menjadi empat tipologi lahan, yaitu : lahan potensial, lahan sulfat masam, lahan gambut dan lahan salin.Oleh karena itu diperlukan upaya-upaya untuk meningkatkan produksi padi yang toleran akan cekaman terutama cekaman salinitas dari beberapa macam genotip padi sawah. Salah satu upaya yang dilakukan untuk meningkatkan hasil padi per satuan luas dapat ditempuh dengan perakitan kultivar padi yang berpotensi hasil tinggi didukung oleh karakteristik low input, tahan terhadap cekaman biotik maupun abiotik, dan berkualitas baik. Dengan demikian ada peluang memperoleh tanaman yang toleran atau adaptif pada kondisi lahan tercekam melalui upaya memanipulasi gen yang mengendalikannya (Ai Komariah, H., 2011). Untuk mengetahui daya hasil dan daya adaptasi dengan lingkungan, pengujian terhadap daya hasil pada lingkungan tercekam salinitas mutlak diperlukan, karena daya hasil atau penampilan tanaman secara keseluruhan merupakan cerminan pengaruh genetik dan nongenetik selama proses perkembangan tanaman yang bersangkutan (Allard and Bradshaw, 1964). Untuk itu diperlukan informasi tentang karakter penting tanaman padi pada kondisi cekaman salinitas, yang meliputi variabilitas genetik dan nilai duga heritabilitas sebagai informasi untuk program pemuliaan selanjutnya.

Berdasarkan latar belakang yang telah dikemukakan di atas maka dapat diidentifikasi masalah sebagai berikut :

Bagaimana variabilitas dan heritabilitas dari karakter penting beberapa genotip padi sawah pada cekaman salinitas tinggi.

\section{METODE PENELITIAN}

Percobaan dilaksanakan di Rumah Kaca Balai Pengawasan dan Sertifikasi Benih Tanaman Pangan dan Hortikultura, Bandung dengan ketinggian tempat $600 \mathrm{~m}$ dpl. Tanah yang digunakan adalah tanah sawah (Grumosol). Percobaan dilaksanakan pada bulan Oktober 2011 sampai dengan bulan Februari 2012. Bahan yang digunakan adalah benih dari 13 genotip padi sawah dan 3 genotip padi rawa pasang surut sebagai kontrol, yaitu BP23f-PN-11 (Varietas Inpari 1), BP1356-1G-KN-4 (Varietas Inpari 2), BP3448E-4-2 (Varietas Inpari 3), BP2280-1E12-2 (Varietas Inpari 4), IR65600-21-2-2 (Varietas Inpari 5 Merawu),BP205D-KN-78-1-8 (Varietas 
Inpari 6 Jete), RUTTST96B-15-1-2-2-2-1 (Varietas Inpari 7 Lanrang), IR73012-15-2-2-1 (Varietas Inpari 8), IR73005-69-1-1-2 (Varietas Inpari 9 Elo), S3382-2d-Pn-4-1 (Varietas Inpari 10 Laeya), BP1178-2F-26 (Varietas Inpari 11), OM2395 (Varietas Inpari 12), dan OM1490 (Varietas Inpari 13); dengan tiga padi genotip IR52952B-3-3-2 (Varietas Dendang), B7809FKN-29-2-3 (Varietas Siak Raya), dan IR07F101 (Varietas Inpara 5). Bahan lain adalah tanah sawah, air, garam , pupuk Urea ( $45 \% \mathrm{~N})$, pupuk

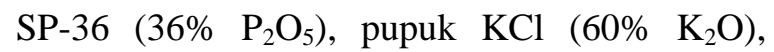
pupuk cair, insektisida Furadan 3G.

Percobaan dilaksanakan di Rumah Kaca dan mempergunakan Rancangan Acak Kelompok (RAK) sederhana terdiri atas 16 perlakuan genotip padi dan masing-masing diulang dua kali.Perlakuan terdiri dari 16 genotip padi dan masing-masing diulang 2 kali. Keenambelas genotip tersebut disusun dengan varietas: $\mathrm{P}_{1}=$ Inpari $1, \mathrm{P}_{2}=$ Inpari $2, \mathrm{P}_{3}=$ Inpari $3, \mathrm{P}_{4}=$ Inpari $4, \mathrm{P}_{5}=$ Inpari 5 Merawu, $\mathrm{P}_{6}=$ Inpari 6 Jete, $\mathrm{P}_{7}=$ Inpari 7 Lanrang, $\mathrm{P}_{8}=$ Inpari $8, \mathrm{P}_{9}=$ Inpari 9 Elo, $\mathrm{P}_{10}=$ Inpari 10 Laeya, $\mathrm{P}_{11}=$ Inpari $11, \mathrm{P}_{12}=$ Inpari $12, \mathrm{P}_{13}=$ Inpari $13, \mathrm{P}_{14}=$ Dendang, $\mathrm{P}_{15}=$ Siak Raya, $\mathrm{P}_{16}$ $=$ Inpara 5Penempatan setiap perlakuan dilakukan secara acak. Setiap perlakuan terdiri atas 6 polybag, sehingga keseluruhan populasi terdapat 192 polybag tanaman.

\section{HASIL DAN PEMBAHASAN}

Pengamatan dilakukan terhadap karakterkarakter morfologis tanaman yang meliputi tinggi tanaman, bobot kering pupus, bobot kering akar, nisbah pupus akar, umur berbunga, umur panen, jumlah malai per rumpun, jumlah gabah isi per rumpun, persentase gabah hampa, bobot 1000 butir dan hasil gabah per rumpun.

1. Keragaman Genotip setiap Karakter

Berdasarkan hasil analisis varians dari karakter-karakter tersebut di atas diperoleh nilai F hitung seperti tersaji pada Tabel 1.

Pada Tabel 1 terlihat adanya keragaman antara genotip untuk karakter-karakter seperti umur berbunga 2,48 ; umur panen 3,16 ; jumlah malai per rumpun 36,41 ; jumlah gabah isi per rumpun 90,91; persentase gabah hampa 46,05 dan bobot 1000 butir 9,77. Sedangkan untuk karakter lainnya seperti tinggi tanaman 1,88 ; bobot kering pupus 0,94 ; bobot kering akar 0,85 ; nisbah pupus akar 0,60 dan hasil gabah per rumpun 1,24 tidak ditemukan keragaman.

Tabel 1. Nilai F hitung untuk Karakter yang Diamati

\begin{tabular}{llcc}
\hline No & \multicolumn{1}{c}{ Karakter yang Diamati } & Fhitung & F0,05 \\
\hline 1 & Tinggi Tanaman & $1,88^{\mathrm{ns}}$ & 2,40 \\
2 & Bobot Kering Pupus & $0,94^{\mathrm{ns}}$ & 2,40 \\
3 & Bobot Kering Akar & $0,85^{\mathrm{ns}}$ & 2,40 \\
4 & Nisbah Pupus Akar & $0,60^{\mathrm{ns}}$ & 2,40 \\
5 & Umur Berbunga & $2,48^{*}$ & 2,40 \\
6 & Umur Panen & $3,16^{*}$ & 2,40 \\
7 & Jumlah Malai per Rumpun & $36,41^{*}$ & 2,40 \\
8 & Jumlah Gabah Isi per Rumpun & $90,91^{*}$ & 2,40 \\
9 & Persentase Gabah Hampa & $46,05^{*}$ & 2,40 \\
10 & Bobot 1000 Butir & $9,77^{*}$ & 2,40 \\
11 & Hasil Gabah per Rumpun & $1,24^{\mathrm{ns}}$ & 2,40 \\
\hline
\end{tabular}

Keterangan $: *=$ Significant $($ Nyata), ns = Non Significant (Tidak Nyata) 
Tabel 2. Nilai Varians Genotip, Varians Fenotip, Standar Deviasi Genotipikdan Standar Deviasi Fenotipik untuk Pengukuran Masing-masingKarakter

\begin{tabular}{llrrrr}
\hline No & \multicolumn{1}{c}{ Karakter yang Diamati } & $\sigma^{2} \mathrm{~g}$ & \multicolumn{1}{c}{$\sigma^{2} \mathrm{p}$} & $\sigma_{\sigma \mathrm{g}}^{2}$ & $\sigma_{\sigma \mathrm{p}}^{2}$ \\
\hline 1 & Tinggi Tanaman & 48,92 & 159,69 & 40,51 & 35,78 \\
2 & Bobot Kering Pupus & $-0,003$ & 0,094 & 0,023 & 0,016 \\
3 & Bobot Kering Akar & $-0,001$ & 0,007 & 0,002 & 0,001 \\
4 & Nisbah Pupus Akar & $-1,10$ & 4,35 & 1,09 & 0,56 \\
5 & Umur Berbunga & 52,28 & 123,07 & 32,43 & 30,07 \\
6 & Umur Panen & 37,45 & 72,15 & 19,71 & 18,79 \\
7 & Jumlah Malai per Rumpun & 22,39 & 23,66 & 7,90 & 7,90 \\
8 & Jumlah Gabah Isi per Rumpun & 480250,76 & 490933,36 & 166566,78 & 166556,70 \\
9 & Persentase Gabah Hampa & 202,56 & 211,55 & 71,04 & 71,02 \\
10 & Bobot 1000 Butir & 12,60 & 15,47 & 4,84 & 4,81 \\
11 & Hasil Gabah per Rumpun & 2,93 & 27,51 & 6,71 & 5,22 \\
\hline
\end{tabular}

2. Nilai Varians Genotip, Varians Fenotip, Standar Deviasi Genotipik dan Standar Deviasi Fenotipik untuk Pengukuran Masing-masing Karakter

Keragaman genotip diestimasi dengan menghitung secara statistik nilai-nilai varians genotip $\left(\sigma^{2} \mathrm{~g}\right)$ dan menghitung standar deviasi genotipik $\left(\sigma_{\sigma}^{2}\right)$ sedangkan keragaman fenotip didekati dengan menghitung secara statistik nilai-nilai varians fenotip $\left(\sigma^{2} p\right)$ dan menghitung standar deviasi fenotipik $\left(\sigma_{\sigma}^{2}\right)$. Nilai varians genotip, varians fenotip, standar deviasi genotipik dan standar deviasi fenotipik untuk masing-masing karakter dapat dilihat pada Tabel 2. Berdasarkan Tabel 2 terlihat bahwa nilai varians fenotip lebih besar dari nilai varians genotip pada semua karakter yang diamati, yaitu berkisar antara 0,007 sampai dengan 490933,35, sedangkan untuk varians genotip berkisar antara $-0,003$ sampai dengan 480250,76. Hal ini disebabkan karena varians fenotip merupakan hasil penjumlahan dari varians genotip dengan lingkungan. Fenomena ini sesuai dengan pendapat yang dikemukakan oleh Johnson, Robinson, dan Comstock (1955), bahwa varians fenotip lebih besar dari pada varians lainnya.

3. Klasifikasi Variabilitas Genotipik
Luas atau sempitnya suatu variabilitas dari karakter yang diamati dapat diketahui dari nilai standar deviasi genotip dan fenotipnya. Dari Tabel 1 di atas diperoleh nilai standar deviasi genotipik berkisar antara 0,002 sampai dengan 166566,78, sedangkan untuk standar deviasi fenotipik didapat nilai 0,001 sampai dengan 166556,70. Berdasarkan ketentuan dari Anderson dan Bancroft (1952), dalam Arthur Pinaria, Achmad Baihaki, Ridwan Setiamiharja dan Aan A. Darajat (1995), yaitu variabilitas luas jika varians lebih besar dari dua kali standar deviasi, dan variabilitas sempit bila varians lebih kecil atau sama dengan dua kali standar deviasi.

Dari klasifikasi variabilitas genotipik pada Tabel 3 dapat diketahui bahwa terdapat empat karakter tanaman yang memiliki nilai variabilitas genotipik luas, yaitu karakter jumlah malai per rumpun $(22,39>15,80)$, jumlah gabah isi per rumpun $(480250,76>333133,56)$, persentase gabah hampa $(202,56>142,07)$ dan bobot 1000 butir $(12,60>9,68)$. Luasnya variabilitas genotipik karakter-karakter tersebut diakibatkan karakter-karakter tersebut banyak dikendalikan oleh banyak gen (polygenic), dan diantara genotip yang diuji terdapat latar belakang gen yang berbeda. 
Tabel 3. Klasifikasi Variabilitas Genotipik

\begin{tabular}{llcccc}
\hline No & \multicolumn{1}{c}{ Karakter yang Diamati } & $\sigma^{2} \mathrm{~g}$ & $\sigma_{\sigma \mathrm{g}}{ }^{2}$ & $2 . \sigma_{\sigma}{ }^{2} \mathrm{~g}$ & Klasifikasi \\
\hline 1 & Tinggi Tanaman & 48,92 & 40,51 & 81,01 & Sempit \\
2 & Bobot Kering Pupus & $-0,003$ & 0,023 & 0,046 & Sempit \\
3 & Bobot Kering Akar & $-0,001$ & 0,002 & 0,004 & Sempit \\
4 & Nisbah Pupus Akar & $-1,10$ & 1,09 & 2,18 & Sempit \\
5 & Umur Berbunga & 52,28 & 32,43 & 64,86 & Sempit \\
6 & Umur Panen & 37,45 & 19,71 & 39,43 & Sempit \\
7 & Jumlah Malai per Rumpun & 22,39 & 7,90 & 15,80 & Luas \\
8 & Jumlah Gabah Isi per Rumpun & 480250,76 & 166566,78 & 333133,56 & Luas \\
9 & Persentase Gabah Hampa & 202,56 & 71,04 & 142,07 & Luas \\
10 & Bobot 1000 Butir & 12,60 & 4,84 & 9,68 & Luas \\
11 & Hasil Gabah per Rumpun & 2,93 & 6,71 & 13,42 & Sempit \\
\hline
\end{tabular}

Tabel 4. Klasifikasi Variabilitas Fenotipik

\begin{tabular}{llcccc}
\hline No & Karakter yang Diamati & \multicolumn{1}{c}{$\sigma^{2} \mathrm{p}$} & \multicolumn{1}{c}{$\sigma_{\sigma \mathrm{p}}^{2}$} & $2 . \sigma_{\sigma}^{2} \mathrm{p}$ & Klasifikasi \\
\hline 1 & Tinggi Tanaman & 159,69 & 35,78 & 71,56 & Luas \\
2 & Bobot Kering Pupus & 0,094 & 0,016 & 0,032 & Luas \\
3 & Bobot Kering Akar & 0,007 & 0,001 & 0,002 & Luas \\
4 & Nisbah Pupus Akar & 4,35 & 0,56 & 1,12 & Luas \\
5 & Umur Berbunga & 123,07 & 30,07 & 60,14 & Luas \\
6 & Umur Panen & 72,15 & 18,79 & 37,58 & Luas \\
7 & Jumlah Malai per Rumpun & 23,66 & 7,90 & 15,80 & Luas \\
8 & Jumlah Gabah Isi per Rumpun & 490933,36 & 166556,70 & 333113,40 & Luas \\
9 & Persentase Gabah Hampa & 211,55 & 71,02 & 142,04 & Luas \\
10 & Bobot 1000 Butir & 15,47 & 4,81 & 9,62 & Luas \\
11 & Hasil Gabah per Rumpun & 27,51 & 5,22 & 10,44 & Luas \\
\hline
\end{tabular}

Menurut Sinha, U. dan S. Sinha (1977), adanya variabilitas genotipik yang luas pada suatu populasi merupakan potensi dasar untuk melakukan suatu program pemuliaan. Adanya variabilitas genotipik yang luas merupakan salah satu syarat dapat berlangsungnya proses seleksi genotip yang efektif, selain bedanya ukuran populasi yang akan memperluas kesempatan dalam seleksi sehingga didapatkan sifat-sifat yang dikehendaki (Allard, 1960).

Jika melihat klasifikasi variabilitas fenotipik pada Tabel 4 semua karakter yang diamati menunjukkan variabilitas fenotipik luas, diantaranya tinggi tanaman $(159,69>71,56)$, bobot kering pupus $(0,094>0,032)$, bobot kering akar $(0,007>0,002)$, nisbah pupus akar $(4,35>1,12)$, umur berbunga $(123,07>60,14)$, umur panen $(72,15>37,58)$, jumlah malai per rumpun $(23,66>15,80)$, jumlah gabah isi per rumpun $(490933,36>333113,40)$, persentase gabah hampa $(211,55>142,04)$, bobot 1000 butir $(15,47>9,62)$ dan hasil gabah per rumpun $(27,51>10,44)$.

Meskipun penampilan fenotipik tanaman dipengaruhi oleh genetik, lingkungan serta interaksi antara genetik dengan lingkungan namun karakter-karakter yang memiliki nilai variabilitas yang luas tersebut menunjukkan bahwa keragaman yang dimunculkan dari karakter tersebut disebabkan oleh faktor genetik dan sedikit sekali dipengaruhi oleh faktor lingkungan, sehingga karakter-karakter tersebut dalam kondisi lingkungan yang berbeda akan menampilkan keragaman yang sama seperti yang dimiliki oleh tetuanya. 
Selain didapat nilai variabilitas yang luas, klasifikasi variabilitas genotipik pada Tabel 2 juga memperlihatkan adanya nilai variabilitas genotipik sempit, antara lain tinggi tanaman $(48,92 \leq 81,01)$, bobot kering pupus $(-0,003 \leq$ $0,046)$, bobot kering akar $(-0,001 \leq 0,004)$, nisbah pupus akar $(-1,10 \leq 2,18)$, umur berbunga $(52,28 \leq 64,86)$, umur panen $(37,45 \leq 39,43)$ dan hasil gabah per rumpun $(2,93 \leq 13,42)$. Hal ini menggambarkan bahwa keragaman yang terjadi dipengaruhi secara dominan oleh faktor lingkungan dan pengaruh faktor genetik sangat kecil, sehingga pada kondisi lingkungan yang berbeda akan menampilkan keragaman yang berbeda pula.

4. Nilai Duga Heritabilitas Karakter Penting Beberapa Genotip Padi Sawah pada Cekaman Salinitas Tinggi

Kriteria yang digunakan pada program pemuliaan tanaman untuk perbaikan sifat-sifat tanaman selain dari nilai variabilitas genotipik diperlukan pula nilai duga heritabilitasnya untuk mengetahui berapa besar peranan gen dalam menentukan ekspresi fenotipnya. Berdasarkan perbandingan antara varians genotip dan varians fenotip dapat ditentukan nilai heritabilitas.

Heritabilitas suatu karakter sangat berpengaruh dalam pemilihan metode perbaikan populasi melalui seleksi. Nilai heritabilitas dalam arti luas dinyatakan dengan kriteria tinggi, sedang dan rendah. Nilai duga heritabilitas yang tinggi menunjukkan bahwa variabilitas suatu tanaman disebabkan oleh faktor genetik, sedangkan nilai duga heritabilitas yang rendah menunjukkan besarnya pengaruh lingkungan terhadap keragamannya.

Kriteria nilai duga heritabilitas menurut Stansfield, W.D. (1983), dibagi menjadi tiga kelas, yaitu :

1. $0,50<\mathrm{H} \leq 1,00$ (heritabilitas tinggi)

2. $0,20 \leq \mathrm{H} \leq 0,50$ (heritabilitas sedang)

3. $0,00 \leq \mathrm{H}<0,20$ (heritabilitas rendah)

Pada Tabel 5 terlihat bahwa nilai heritabilitas yang tinggi dimiliki oleh karakter umur panen 0,52 ; jumlah malai per rumpun 0,95; jumlah gabah isi per rumpun 0,978; persentase gabah hampa 0,96 dan bobot 1000 butir 0,81. Hal ini menunjukkan bahwa penampilan karakter-karakter tersebut lebih ditentukan oleh faktor genetik dibandingkan dengan faktor lingkungan. Heritabilitas yang tinggi pada karakter yang diamati menunjukkan bahwa karakter-karakter tersebut mudah diwariskan kepada keturunannya.Untuk karakter tinggi tanaman 0,31 dan umur berbunga 0,42 termasuk pada nilai heritabilitas sedang, artinya antara faktor genetik dan faktor lingkungan tidak ada yang memberikan pengaruh dominan. Ini menandakan bahwa tiap genotip walaupun berasal dari tetua dan susunan gen yang berbeda, pada saat ditanam pada lingkungan yang sama dan dalam kondisi yang tercekam ternyata memberikan reaksi yang hampir sama.

Tabel 5. Nilai Duga Heritabilitas Karakter Penting Beberapa Genotip PadiSawah pada Cekaman Salinitas Tinggi

\begin{tabular}{llcccc}
\hline No & Karakter yang Diamati & $\sigma^{2} \mathrm{~g}$ & $\sigma^{2} \mathrm{p}$ & $\begin{array}{c}\text { Nilai } \\
\text { Heritabilitas }\end{array}$ & Kriteria \\
\hline 1 & Tinggi Tanaman & 48,92 & 159,69 & 0,31 & Sedang \\
2 & Bobot Kering Pupus & $-0,003$ & 0,094 & $-0,028$ & Rendah \\
3 & Bobot Kering Akar & $-0,001$ & 0,007 & $-0,082$ & Rendah \\
4 & Nisbah Pupus Akar & $-1,10$ & 4,35 & $-0,25$ & Rendah \\
5 & Umur Berbunga & 52,28 & 123,07 & 0,42 & Sedang \\
6 & Umur Panen & 37,45 & 72,15 & 0,52 & Tinggi \\
7 & Jumlah Malai per Rumpun & 22,39 & 23,66 & 0,95 & Tinggi \\
8 & Jumlah Gabah Isi per Rumpun & 480250,76 & 490933,36 & 0,978 & Tinggi \\
9 & Persentase Gabah Hampa & 202,56 & 211,55 & 0,96 & Tinggi \\
10 & Bobot 1000 Butir & 12,60 & 15,47 & 0,81 & Tinggi \\
11 & Hasil Gabah per Rumpun & 2,93 & 27,51 & 0,11 & Rendah \\
\hline
\end{tabular}


Sedangkan untuk nilai heritabilitas yang rendah terdapat pada karakter bobot kering pupus 0,028; bobot kering akar -0,082; nisbah pupus akar $-0,25$ dan hasil gabah per rumpun 0,11 . Rendahnya nilai heritabilitas diakibatkan karakter-karakter tersebut variasinya lebih dipengaruhi oleh faktor lingkungan, artinya faktor lingkungan lebih dominan daripada faktor genetik dan kecil kemungkinan diwariskan pada generasi selanjutnya, karena dapat berubah pada kondisi lingkungan yang berbeda, sehingga meskipun dapat dilakukan seleksi yang diperoleh kemajuannya kecil.

\section{KESIMPULAN DAN SARAN}

Berdasarkan hasil percobaan variabilitas dan heritabilitas karakter penting beberapa genotip padi sawah pada cekaman salinitas tinggi dapat ditarik kesimpulan sebagai berikut :

1. Terdapat variabilitas genotipik yang luas untuk jumlah malai per rumpun (22,39 > 15,80), jumlah gabah isi per rumpun $(480250,76>333133,56)$, persentase gabah hampa $(202,56>142,07)$ dan bobot 1000 butir $(12,60>9,68)$. Serta terdapat variabilitas fenotipik yang luas untuk semua karakter yang diamati, diantaranya tinggi tanaman $(159,69>71,56)$, bobot kering pupus $(0,094>0,032)$, bobot kering akar $(0,007>0,002)$, nisbah pupus akar $(4,35>$ $1,12)$, umur berbunga $(123,07>60,14)$, umur panen $(72,15>37,58)$, jumlah malai per rumpun $(23,66>15,80)$, jumlah gabah isi per rumpun $(490933,36>333113,40)$, persentase gabah hampa $(211,55>142,04)$, bobot 1000 butir $(15,47>9,62)$ dan hasil gabah per rumpun $(27,51>10,44)$.

2. Terdapat nilai duga heritabilitas yang berbeda-beda untuk karakter-karakter penting padi sawah pada cekaman salinitas tinggi. Nilai heritabilitas yang tinggi dimiliki oleh karakter umur panen 0,52; jumlah malai per rumpun 0,95 ; jumlah gabah isi per rumpun 0,978 ; persentase gabah hampa 0,96 dan bobot 1000 butir 0,81 . Untuk karakter tinggi tanaman 0,31 dan umur berbunga 0,42 termasuk pada nilai heritabilitas sedang. Sedangkan untuk nilai heritabilitas yang rendah terdapat pada karakter bobot kering pupus -0,028; bobot kering akar -0,082; nisbah pupus akar $-0,25$ dan hasil gabah per rumpun 0,11 .

\section{Saran}

Untuk mendapatkan informasi yang lebih lengkap, didasarkan pada hasil percobaan ini dapat diajukan beberapa saran sebagai berikut :

1. Perlu dilakukan percobaan yang sama untuk mendapatkan karakter-karakter penting lain dari beberapa genotip padi sawah pada cekaman salinitas tinggi.

2. Perlu dilakukan percobaan lebih lanjut tentang genotip padi sawah pada cekaman salinitas dengan menggunakan tingkatan salinitas yang berbeda-beda. 


\section{DAFTAR PUSTAKA}

ACIAR-SADI. 2009. Peningkatan Hasil Panen Padi untuk Kebutuhan Pangan Nasional. Lembar Fakta Program ACIAR Kabar Terkini 1.5 August 2009. Australian Centre for Indonesian Agricultural Research, Makassar.

Ai Komariah, H. 2011. Tanaman Pada Lingkungan Tercekam Jilid 2. Winaya Mukti University Press, Bandung.

Allard, R. W. 1960. Principle of Plant Breeding. John Wiley and Sons. New York.

Allard, R. W. and A. D. Bradshaw. 1964. Implications of Genotypes Enviromental Interactions in Applied Plant Breeding. Crop Science 4 : 503-508.

Hasil Sembiring and Anischan Gani. 2005. Adaptasi Varietas Padi pada Tanah Terkena Tsunami. Balai Besar Penelitian Tanaman Padi, Sukamandi.

Johnson, H.W., H.F. Robinson and R.E. Comstock. 1955. Estimates of Genetic and Environmental Variability in Soybean. Agr. J. $47: 314-318$.

Pinaria Arthur, Achmad Baihaki, Ridwan Setiamiharja dan Aan A. Darajat. 1995.
Variabilitas Genetik dan Heritabilitas Karakter-karakter Biomasa 53 Genotip Kedelai. Zuriat 6 (2) : 88 - 92. PERIPI, Komda Jawa Barat.

Sinha, U. and S. Sinha. 1977. Cytogenic Plant Breeding and Evolution. Vikas Publishing House Pub. Ltd., New Delhi.

Stansfield, W. D. 1983. Genetics. McGraw Hill Book Company, New York.

Sumarsono, S. Anwar, S. Budianto dan D. W. Widjayanto. 2006. Penampilan Morfologi dan Produksi Bahan Kering Hijauan Rumput Gajah dan Kolonjono di Lahan Pantai yang Dipupuk dengan Pupuk Organik dan Dua Level Pupuk Urea. Fakultas Peternakan Universitas Dipenogoro, Semarang.

Widjaja - Adhi, Subiksa, Sutcipto Ph. dan B. Radjagukguk. 1990. Pengelolaan Tanah dan Air Lahan Pasang Surut, Studi Kasus Karang Agung, Sumatera Selatan. Dalam Usaha Tani di Lahan Pasang Surut dan Rawa. Risalah Seminar Hasil Penelitian Proyek Swamps II. Bogor, 19 - 21 September 1989.

\footnotetext{
Penulis Pertama dan Kedua adalah Staf
} Pengajar di Fakultas Pertanian Unwim 